\title{
KETERLIBATAN PENULIS MELALUI ASPEK KEBAHASAAN PADA BUKU TEKS PELAJARAN BERLANDASKAN KURIKULUM 2013
}

\author{
Ahmad Fadly \\ Pendidikan Bahasa dan Sastra Indonesia, Fakultas Ilmu Pendidikan, \\ Universitas Muhammadiyah Jakarta \\ Jalan KH. Ahmad Dahlan, Ciputat, Cirendeu, Jakarta Selatan 15419 \\ ahmad.fadly@umj.ac.id
}

\begin{abstract}
ABSTRAK
Buku teks pelajaran (buku TP) berpengaruh pada pengetahuan, pemahaman, dan cara pandang peserta didik. Buku TP Sejarah menentukan pemahaman peserta didik mengenai identitas bangsa di masa lalu sehingga dapat menjadi dasar tindakannya di masa depan. Keterlibatan penulis buku TP Sejarah tercermin melalui aspek kebahasaannya. Keterlibatan itu menunjukkan sikap penulis terhadap pengetahuan yang disajikannya melalui buku tersebut. Dengan menganalisis tiga buku TP Sejarah Kelas X, Kelas XI, dan Kelas XII menggunakan subsistem keterlibatan (engagement), terungkap bahwa heteroglossia hadir dalam buku TP Sejarah Kelas X, XI, dan XII, tetapi memiliki karakteristik tersendiri. Pada buku TP Sejarah Kelas X, penulis menggunakan heteroglossia dengan mengutip informasi faktual-objektif untuk mendukung argumennya, sedangkan pada buku TP Sejarah Kelas XI penulis menggunakan heteroglossia dengan mengutip pendapat yang bersifat subjektif untuk mendukung argumennya. Sementara itu, pada buku TP Sejarah Kelas XII penulis menggunakan heteroglossia untuk membentuk wacana pada buku tersebut. Pronomina kita secara intensif digunakan dan tidak digunakan pronomina kami atau saya pada ketiga buku tersebut. Artinya, penulis berstrategi untuk mengurangi tanggung jawabnya terhadap teks yang ditulisnya. Temuan lain ialah bahwa tamengan (hedges) lebih jarang ditemukan dibandingkan dengan boosters dan penggunaan pronomina inklusif (kita) hadir dengan frekuensi tinggi pada ketiga buku tersebut. Ini berarti bahwa dalam menjelaskan sejarah, penulis cenderung menggunakan bahasa evaluatif dengan meningkatkan derajat kualitas (uptoning).
\end{abstract}

Kata kunci: keterlibatan; sistem appraisal; analisis wacana; buku teks pelajaran

PENDAHULUAN

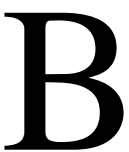

dalam pembelajaran di sekolah. Keberadaannya menunjang tercapainya kompetensi yang ditargetkan. Di tengah era keterbukaan dan kemudahan akses terhadap 
informasi, buku TP masih menjadi "jendela" ilmu pengetahuan. Lebih-lebih, buku itu kini dapat diakses dan diunduh tanpa bayar. Buku tersebut menyediakan kompetensi yang diharapkan, tujuan pembelajaran, materi, hingga evaluasi. Dalam pembelajaran tatap muka, buku TP seringkali dijadikan sebagai sumber belajar utama. Kelengkapan isi dan kesesuaiannya dengan kurikulum yang digariskan menjadi sebabnya.

Sejak diberlakukannya Kurikulum 2013, buku TP disusun dan disesuaikan dengan capaian kompetensi yang diharapkan dari kurikulum itu. Dengan disediakannya secara daring, pelbagai buku TP berlandaskan Kurikulum 2013 terdistribusi secara luas sehingga kendala ekspedisi teratasi. Penggunaannya dalam pembelajaran secara masif dapat dilakukan. Luasnya distribusi dan penggunaan buku TP berlandaskan Kurikulum 2013 mengharuskan kecermatan dalam penyusunannya. Sebab, buku pelajaran berdampak besar pada pemahaman peserta didik, bahkan pada pembentukan ideologinya.

Pelbagai pelajaran ditawarkan melalui buku-buku berlandaskan Kurikulum 2013 yang diterbitkan oleh Kementerian Pendidikan dan Kebudayaan Republik Indonesia. Rumpun Sosial Humaniora (Soshum) dan Sains Teknologi (Saintek) disediakan, sesuai dengan minat dan jurusannya. Pada buku TP dengan rumpun saintek, ruang penulis untuk "berimprovisasi" dari segi bahasanya relatif lebih sempit daripada rumpun Soshum. Kebenaran yang bersifat tunggal, sebagaimana diyakini oleh penganut paham positivistik, membatasi penulis dengan garis demarkasi yang lugas. Sebaliknya, buku TP dengan rumpun ilmu soshum memberi keleluasaan kepada penulis untuk menawarkan sudut pandang yang variatif. Luasnya ruang interpretasi dan keterlibatan penulis dapat memengaruhi pemahaman peserta didik. Oleh karena itu, buku-buku TP dengan rumpun ilmu soshum memerlukan kajian secara kritis, baik dari segi isi maupun bahasa yang digunakan.

Ditinjau dari jumlahnya, buku TP rumpun ilmu soshum memiliki "konsumen" yang besar. Selain itu, umumnya mereka terkategori sebagai generasi muda yang kelak menjadi penerus dan bahkan pemimpin bangsa. Pembacaan terhadap buku TP dapat memengaruhi cara pandang, ideologi, bahkan tindakannya. Dengan demikian, berlaku alur berpikir kolektif: Yang dikonsumsi (kelak) menentukan yang diproduksi.

Pelbagai kajian terhadap buku TP berumpun ilmu soshum telah diwujudkan. Ada yang memberi catatan kritis terhadap buku pelajaran agama dan menyintesiskan minimnya pemahaman gender di dalamnya (Murfi, 2014). Ada pula yang mengevaluasi kualitas buku TP sejarah, lalu merekomendasikan bahwa buku TP Sejarah perlu perbaikan dalam hal pendekatan, kesamaan, dan integrasi nasional (Purwanta, 2013). Di antara variatifnya buku pelajaran berumpun ilmu soshum, buku TP Sejarah menarik untuk dikaji dari aspek kebahasaannya, mengingat bahwa ruang interpretasi dan keterlibatan penulis berperan penting dalam membentuk narasi sejarah. Bidang ilmu itu dipelajari dan diajarkan kepada peserta didik kelompok soshum dengan pelbagai latar belakang suku, agama, etnis, dan golongan. Kenyataan ini berbeda dengan buku pelajaran agama yang disegmentasikan sebatas untuk peserta didik yang didasarkan pada agama yang diyakininya. 
Dari sisi kontennya, buku TP Sejarah menggambarkan rekam jejak pengalaman bangsa, bahkan mengungkap tabir identitas bangsa di masa lalu. Penulis buku sejarah - melalui bahasanya - dapat memengaruhi wacana peserta didik atau publik. Uniknya, buku sejarah seringkali tidak ditulis oleh pelaku atau pengalam sejarah itu sendiri. Akibatnya, peristiwa masa lalu itu dikisahkan secara beragam, bergantung pada gaya bahasa penulisnya. Keterlibatan penulis dari aspek kebahasaan menggambarkan sikapnya dan dapat menentukan arah pemahaman atas wacana historis yang dikisahkan. Kajian mengenai buku TP Sejarah telah dilakukan (Purwanta, 2013), tetapi penelitiannya tidak menekankan keterlibatan penulis dari aspek linguistisnya. Lebih dari itu, kajiannya difokuskan sebatas pada masa Orde Baru sehingga konten dan bahasanya cenderung homogen, sesuai dengan yang digariskan oleh penguasa.

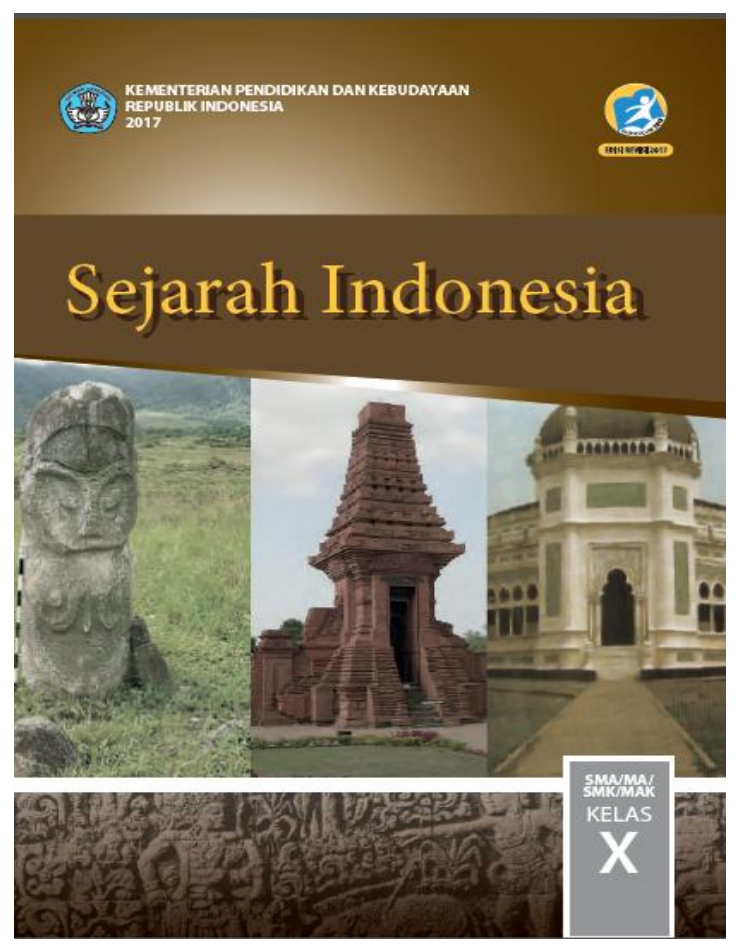

Gambar 1 Buku TP Sejarah Kelas X

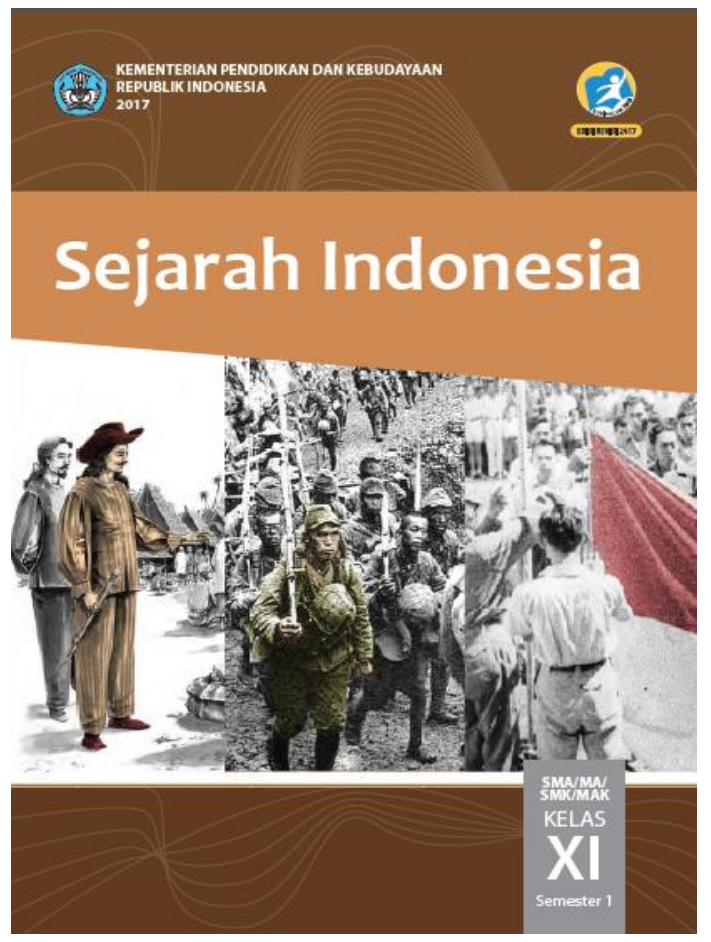

Gambar 2 Buku TP Sejarah Kelas XI

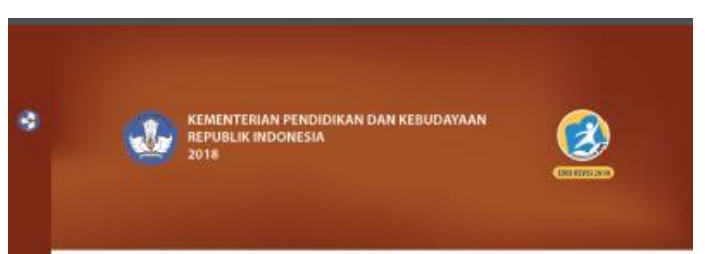

\section{Sejarah Indonesia}

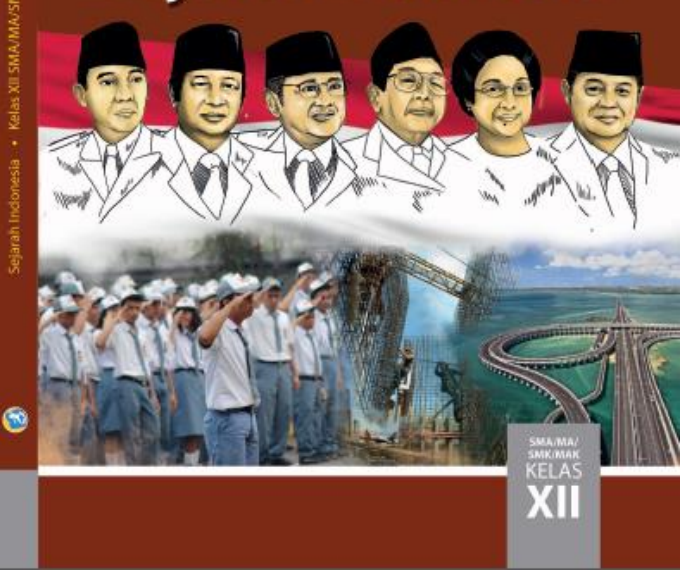

Gambar 3 Buku TP Sejarah Kelas XII

Kajian yang mengandalkan fitur stansial dan keterlibatan telah dilakukan oleh beberapa peneliti (Biber, 2006; Kafes, 2018; Yang, 2016). Bahkan kajian terkini melibatkan organisasi retoris dalam analisis 
wacana akademis (Kurniawan, Lubis, Suherdi, \& Danuwijaya, 2019). Akan tetapi, beragam penelitian tersebut menggunakan artikel jurnal sebagai sumber datanya, yang memiliki "konsumen" peneliti atau setidaknya kalangan akademis. Para pembaca itu umumnya telah memiliki fondasi keilmuan dan juga keyakinan yang cukup sehingga keterlibatan penulis tidak banyak berdampak secara ideologis. Oleh sebab itu, peneliti ini mengkaji buku teks pelajaran sejarah berlandaskan Kurikulum 2013 (yang ditulis jauh setelah masa Orde Baru) dengan mengungkap keterlibatan penulis berdasarkan aspek kebahasaannya.

Dalam analisisnya, peneliti ini mengandalkan teori keterlibatan (engagement), yang merupakan subsistem appraisal seperti yang ditawarkan oleh Martin dan White (2005). Mereka menawarkan sistem Appraisal yang terbagi atas tiga subsistem, yaitu attitude, graduation, dan engagement (Martin; \& White, 2005). Penelitian ini difokuskan pada subsistem keterlibatan (engagement) penulis dalam buku teks tersebut. Keterlibatan penulis buku TP tercermin dalam heteroglossia dan monoglossia yang hadir dalam teks. Secara khusus, peneliti ini juga mengoperasikan rincian keterlibatan, yang mencakup reader pronoun, directives, questions, shared knowledge, dan personal aside yang dikombinasikan dengan fitur stansial yang meliputi hedges, boosters, attitude markers, dan self-mentions (Hyland, 2005; Sayah \& Hashemi, 2014). Fitur stansial menitikberatkan pada kecenderungan penulis dalam interaksi dan cara penulis menganotasi teksnya.

Dalam penulisannya, penulis buku umumnya mengharapkan adanya interaksi dari pembacanya. Interaksi itu melibatkan pemosisian (positioning) atau adopsi sudut pandang terhadap isu yang dibahas dalam teks ataupun pembacanya (Hyland, 2005). Meskipun buku merupakan media komunikasi satu arah, interaksi dapat terjadi dalam pelbagai variasi, seperti resensi, kritik, saran, dan ulasan terhadap buku tersebut. Oleh sebab itu, interaksi akademis dalam ragam tulis (buku) tidak bersifat langsung. Atas dasar interaksi itu, buku dapat dikategorikan sebagai wacana akademis. Dalam wacana itu, penulis buku TP menggunakan bahasa dalam fungsinya sebagai interpersonal meskipun interaksi tersebut sifatnya tidak langsung. Untuk menjalin hubungan dengan pembacanya, penulis buku TP mengevaluasi pengetahuan mengenai sejarah, lalu mengartikulasikannya kepada pembaca.

\section{METODE PENELITIAN}

Denelitian kualitatif ini menggunakan
metode analisis isi. Peneliti ini menggunakan tiga buku TP Sejarah jenjang SMA Kelas X, XI, dan XII berlandaskan Kurikulum 2013 sebagai sumber data. Buku TP Sejarah kelas X merupakan cetakan ke4 (edisi revisi) tahun 2017 yang ditulis oleh Restu Gunawan, Amurwani Dwi Lestariningsih, dan Sardiman. Buku TP Sejarah kelas XI merupakan cetakan ke-2 (edisi revisi) tahun 2017 yang ditulis oleh Sardiman A.M. dan Amurwani Dwi Lestariningsih. Sementara itu, buku TP Sejarah kelas XII merupakan cetakan ke-2 (edisi revisi) tahun 2018 dengan penulis Abdurakhman, Arif Pradono, Linda Sunarti, dan Susanto Zuhdi. Ketiga buku tersebut diterbitkan oleh Kementerian Pendidikan dan Kebudayaan Republik Indonesia.

Ketiga buku itu diklasifikasikan ke dalam unit analisis. Tujuannya untuk 
memudahkan peneliti dalam menganalisisnya.

\section{HASIL DAN PEMBAHASAN}

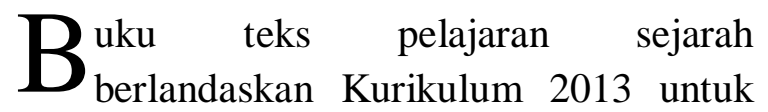
tingkat SMA mengandungi keterlibatan penulisnya. Peneliti ini membatasi temuan reader pronoun, questions, shared knowledge, personal aside, hedges, boosters, attitude marker, dan self-mentions pada teks-teks monoglossik atau yang bukan merupakan kutipan. Cara itu dilakukan untuk mengungkap keterlibatan penulis melalui bahasa yang digunakannya, bukan bahasa yang dikutipnya. Penelitian ini mengklasifikasikan temuan atau hasil berdasarkan jenjang pendidikan buku TP sebagai sumber data, yaitu Kelas X, XI, dan XII.

\section{Buku TP Kelas X}

Pada buku TP Kelas $\mathrm{X}$ ditemukan heteroglossia dengan mengutip dari Arysio Santos sejak awal Bab I. Kutipan itu mengenai kondisi geografis Indonesia yang rentan terhadap bencana gempa dan letusan gunung api. Kutipan tersebut menjadi dasar opini penulis dengan menggunakan pronomina inklusif kita. Kondisi geografis Indonesia yang objektif meyakinkan penulis untuk menjalin komunikasi interpersonal kepada pembaca. Dengan demikian, heteroglossia kondisi faktualobjektif digunakan untuk mendukung komunikasi interpersonal dengan melibatkan pronomina yang mengacu pada pembaca.

Kehadiran personal aside terdapat pada buku TP Kelas X ini. Mengingat bahwa ini merupakan buku TP, pada bagian tujuan pembelajaran digunakan pronomina kamu dengan tujuan interaksi kepada pembaca secara eksklusif. Penggunaan pronomina itu dapat memberikan impresi yang atensi lebih karena menyapa secara personal, bukan komunal. Selain itu, pada Bab I bagian uraian materi, penulis menggunakan pronomina kalian yang berarti bertujuan interaksi kepada pembaca secara komunal.

Dari sisi appeals to shared knowledge, penulis berusaha untuk "mengikat" pembaca pada persetujuan atau penerimaan atas pengetahuan yang dituliskan. Pada bagian teks berikut menunjukkan kehadiran elemen tersebut.

Pertanyaan yang sulit untuk dijawab adalah kapan tepatnya manusia itu ada di bumi ini sebagai pertanda dimulainya zaman praaksara? Untuk menjawab pertanyaan itu kamu perlu memahami kronologi perjalanan kehidupan di permukaan bumi yang rentang waktunya sangat panjang. (Halaman 5)

Kalimat pertama menunjukkan bahwa penulis mengikat pemahaman pembaca dengan meminta menyetujui bahwa ada pertanyaan (yang menurut penulis) sulit untuk dijawab. Kalimat kedua juga mengisyaratkan bahwa pembaca harus memenuhi syarat (pemahaman atas kronologi perjalanan kehidupan yang sangat panjang) yang diajukan oleh penulis. Kalimat kedua itu juga menunjukkan komunikasi diarahkan secara langsung (directives) dengan menyebutkan modalitas perlu. Sementara itu, kalimat pertama berupa pertanyaan menunjukkan strategi keterlibatan dialogis penulis untuk "membawa" pembaca sebagai mitra tutur 
(interlocutor) ke dalam arena pemahaman dan sudut pandang penulis.

Sementara itu, dari aspek tamengan (hedges), penulis membuka ruang diskursif dengan mengambil "jarak aman" dari ketidaksetujuan pembaca. Tamengan berfungsi untuk memperlunak (downtoner) pernyataan penulis. Kehadiran tamengan hanya ditemukan 7 kemunculan. Salah satunya terdapat pada kalimat Sebelum bumi didiami manusia, kepulauan ini hanya diisi flora dan fauna yang masih sangat kecil dan sederhana. (Halaman 11)

Pada kalimat itu tersurat leksikon sangat diikuti dengan kecil. Artinya, penulis menggunakan tamengan untuk memperlunak atau menurunkan derajat kualitas ukuran flora dan fauna. Meskipun demikian, penggunaan pronomina kita, sebagaimana diuraikan pada elemen reader pronoun, dapat dikategorikan sebagai tamengan. Sebab, pronomina kita berfungsi sebagai strategi untuk mengurangi tanggung jawab penulis dari teks yang ditulisnya (Dzeverdanovic-Pejovic, 2015).

Di sisi lain, boosters lebih banyak digunakan. Terdapat 111 boosters yang hadir dalam buku TP Sejarah Kelas X. Dua di antaranya terdapat pada kalimat berikut.

1. Oleh karena itu, kemampuan melakukan analisis berbagai peristiwa sejarah sangat diperlukan. (Halaman iii)

2. Namun sebelum itu marilah kita sebentar berkenalan dengan kondisi alamnya, terutama unsur-unsur geologi atau unsur-unsur geodinamika yang sangat berperan dalam pembentukan Kepulauan Indonesia. (Halaman 11)

Kehadiran attitude markers sebagian mengiringi boosters dan juga tamengan. Elemen attitude markers lebih mengindikasikan afeksi penulis daripada epistemiknya. Sikap itu tercermin melalui proposisinya. Ditemukan 133 attitude markers pada buku TP Sejarah Kelas X. Tiga di antaranya pada kalimat berikut.

1. Di bawah ini akan dipaparkan beberapa penemuan penting fosil manusia di beberapa tempat. (Halaman 13)

2. Sebagai missal, karakter evolutif yang paling signifikan adalah bertambahnya kapasitas otak. (Halaman 25)

3. Temuan Wajak menunjukkan pada kita bahwa sekitar 40.000 tahun yang lalu Indonesia sudah didiami oleh Homo Sapiens yang rasnya sukar dicocokkan dengan ras-ras pokok yang terdapat sekarang, sehingga manusia Wajak dapat dianggap sebagai suatu ras tersendiri. (Halaman 27)

Ditinjau dari self-mentions, penulis tidak menggunakannya. Elemen selfmentions mengacu pada penggunaan pronomina orang pertama dan adjektif posesif untuk menampilkan proposisi, afeksi, dan informasi interpersonal (Hyland, 2005). Dalam buku TP Sejarah Kelas $\mathrm{X}$ terungkap bahwa penggunaan pronomina pertama saya tidak muncul sebab penulis buku tersebut terdiri atas tiga orang. Meskipun demikian, pronomina kami pun tidak digunakan. Ini menunjukkan bahwa penulis berhatihati dalam menawarkan sudut pandangnya dalam menyajikan materi sejarah. Pronomina inklusif kita (sebagaimana dijelaskan pada elemen reader pronoun di atas) justru lebih banyak muncul, yang menunjukkan bahwa penulis mengharapkan interaksi antara mereka dan pembaca.

2. Buku TP Kelas XI 
Pada buku TP Kelas XI ditemukan heteroglossia dengan mengutip dari H.A. Notosoetardjo mengenai negerinegeri mandat sebagai buah imperialisme zaman sekarang di awal Bab I.

Kutipan itu mendasari opini penulis melalui penggunaan pronomina kedua kamu dan pronomina inklusif kita. Kutipan tersebut, oleh penulis dikaitkan dengan kemerdekaan politis yang berbeda dengan kemerdekaan ekonomi. Heteroglossia hadir dalam teks meskipun penulis menggunakan "suara" H.A Notosoetardjo yang berupa pendapat (subjektif).

Kehadiran personal aside terdapat pada buku TP Kelas XI dengan intensitas yang tinggi. Penggunaan pronomina inklusif kita dan pronomina kamu (sebagai penyapa orang kedua yang eksklusif) ditemukan. Pronomina kamu diharapkan lebih memberikan impresi personal dibandingkan pronomina kalian. Kehadiran personal aside itu ada pada kalimat berikut.

Kamu sering mendengar kritik bahwa secara politis kita sudah merdeka tetapi secara ekonomis masih sering dipermainkan oleh kekuatan ekonomi global. (Halaman 1)

Kalimat itu mengindikasikan adanya elemen appeals to shared knowledge. Pada kalimat tersebut penulis berusaha memberi pilihan tunggal: setuju atas pengetahuan yang dituliskan mengenai seringnya mendengar pernyataan perihal perbedaan merdeka secara politis dan ekonomis. Dari sisi langsung atau tidaknya (directives), kalimat tersebut merupakan bentuk komunikasi langsung karena menggunakan pronomina langsung (kamu).

Langsungnya komunikasi juga tampak pada ketiga kalimat tanya berikut.

Mengapa hal itu terjadi? Mengapa

kemandirian di bidang ekonomi kita masih lemah? Mengapa jati diri di bidang kebudayaan juga kurang kompetitif? (Halaman 1)

Ketiga pertanyaan itu mengungkap strategi keterlibatan penulis yang memberi pilihan tunggal kepada pembaca untuk menyetujui bahwa kemandirian ekonomi Indonesia masih lemah dan meminta pembaca sebagai mitra tutur untuk memikirkan sebabnya. Berdasarkan tamengan yang hadir dalam buku TP Sejarah Kelas XI, terungkap di halaman 53 berikut.

Keadaan ekonomi Belanda semakin berat. Sebab, Belanda banyak kehilangan lahan industri sehingga pemasukan negara juga semakin berkurang. (Halaman 53)

Sama halnya pada buku TP Kelas X, kehadiran boosters pada buku TP Kelas XI juga lebih banyak dibandingkan dengan tamengan. Adanya boosters itu terungkap pada kalimat berikut.

Dengan membawa dan memperdagangkan hasil tanaman sebanyak-banyaknya ke Eropa, maka akan mendatangkan keuntungan yang sangat besar. (Halaman 54)

Elemen attitude marker muncul pada halaman 50 pada kalimat berikut.

Budaya dan kebiasaan petani sulit diubah, pengawasan pemerintah kurang, dalam mengatur rakyat peran kepala desa dan bupati lebih kuat daripada asisten residen yang 
berasal dari orang-orang Eropa.

(Halaman 50)

Sementara itu, elemen self-mentions tidak ditemukan dalam buku TP Kelas XI, mengingat bahwa penulisnya berjumlah dua orang.

\section{Buku TP Kelas XII}

Pada buku TP Kelas XII ditemukan heteroglossia dengan mengutip dari C.S.T. Kansil dan Julianto mengenai ancaman disintegrasi sebagai musuh terbesar bangsa.

Penggunaan "suara" orang lain dilakukan oleh penulis untuk mendukung tema besar yang ditawarkan pada Bab I. Kutipan itu tidak secara langsung dianotasi, tetapi diteruskan dengan ilustrasi atau foto yang menggambarkan beberapa orang tewas tergeletak di jalanan. Setelah itu, penulis memaparkan fakta perihal baru dirayakannya hari kebangkitan nasional setelah 40 tahun pada teks berikut.

Tahukah kalian bahwa sesudah 40 tahun lamanya, baru pertama kali peringatan Hari Kebangkitan Nasional $20 \mathrm{Mei}$ diselenggarakan pada tahun 1948. (Halaman 2)

Elemen personal aside mengiringi paparan tersebut melalui pronomina kalian. Penulis berupaya menjalin interaksi dengan pembaca secara kolektif sehingga dipahami bahwa informasi faktual mengenai perayaan hari kebangkitan nasional tersebut perlu diketahui bersama.

Ditinjau dari elemen appeals to shared knowledge, terungkap pada kalimat Dalam aksi pengambilalihan tanah - terutama di Jawa Tengah dan Jawa Timur, juga Bali, Jawa Barat dan Sumatra
Utara-massa PKI pun terlibat dalam pertentangan yang sengit dengan, tentu saja, para tuan tanah, juga kaum birokrat dan para pengelola yang berasal dari kalangan tentara. (Halaman 19)

Pada kalimat tersebut penulis berupaya mendorong pembaca pada pengetahuan perihal kelompok yang terlibat pertentangan dengan massa PKI, yaitu para tuan tanah, birokrat, dan pengelola dari kalangan tentara. Penggunaan modalitas tentu saja menjadi penanda adanya upaya tersebut.

Meskipun umumnya digunakan komunikasi tidak langsung dengan kalimat deklaratif, pada buku TP Sejarah Kelas XII seringkali digunakan pola tanya-jawab. Pronomina kalian dan kamu digunakan pada teks tersebut. Tidak ada alasan atau klasifikasi tema yang pasti, yang menyebabkan kedua pronomina itu sama-sama digunakan dalam buku TP Sejarah Kelas XII.

Berdasarkan tamengan yang hadir dalam buku TP Sejarah Kelas XII, ditemukan pada halaman 101 pada kalimat berikut.

Kondisi perekonomian yang sangat merosot mendorong pemerintah berusaha mendapatkan devisa kredit (kredit impor) jangka panjang yang harus dibayar kembali setelah satu atau dua tahun. (Halaman 101)

Frasa sangat merosot menandai adanya tamengan sangat yang diikuti oleh kondisi negatif: merosot. Penulis berusaha menurunkan derajat merosotnya kondisi perekonomian dengan menggunakan tamengan sangat. 
Di samping itu, tamengan terungkap di halaman 166 pada kalimat berikut.

Kepercayaan masyarakat terhadap Presiden Abdurrahman Wahid dan jajaran pemerintahannya semakin menipis seiring dengan adanya dugaan bahwa Presiden terlibat dalam pencairan dan penggunaan dana Yayasan Dana Kesejahteraan Karyawan (Yanatera) Bulog sebesar 35 miliar rupiah dan dana bantuan Sultan Brunei Darussalam sebesar 2 juta dollar AS. (Halaman 166).

Pada kalimat itu, pilihan kata semakin yang diikuti oleh menipis menunjukkan bahwa penulis derajat kualitas menipisnya itu. Tidak banyak ditemukan tamengan pada teks tersebut. Kenyataan ini berbeda dengan boosters yang lebih tinggi frekuensinya. Elemen boosters terlihat pada kalimat berikut ini.

Melalui telegram dan amanat ini, sangat terlihat sikap nasionalisme

Sultan Hamengku Buwono IX. (Halaman 38)

Selain itu, booster tampak pada kalimat Ini adalah nilai uang yang sangat besar. (Halaman 40)

Elemen attitude marker muncul pada halaman yang menyatakan bahwa Kabinet Burhanuddin Harahap mempunyai tugas penting untuk menyelenggarakan pemilihan umum. (Halaman 57)

Di samping itu, attitude marker hadir pula pada kalimat Padahal Presiden Soekarno menaruh harapan besar terhadap Pemilu 1955, karena bisa dijadikan sarana untuk membangun demokrasi yang lebih baik. (Halaman 81)

Sama halnya dengan kedua buku TP lainnya, pada buku TP Sejarah Kelas XII tidak ditemukan elemen selfmentions. Ini membuktikan bahwa dalam menjelaskan penulis menjaga jarak dari proposisi yang digunakannya.

\section{KESIMPULAN}

B uku teks pelajaran turut memengaruhi cara pandang peserta didik. Materi sejarah pada buku teks berkontribusi pada pembentukan ideologi peserta didik, kecintaan, dan keberpihakannya pada bangsa. Keterlibatan penulis buku teks sejarah merupakan aspek penting dalam buku teks sejarah. Keterlibatan yang tampak dari aspek linguistik itu menunjukkan sikap penulis atas apa yang ditulisnya.

Dalam buku TP Sejarah Kelas X ditemukan bahwa penulis menggunakan heteroglossia yang bersifat faktual-objektif untuk mendukung opininya dan menjalin komunikasi interpersonal kepada pembaca dengan penggunaan pronomina inklusif kita. Elemen tamengan jauh lebih sedikit dibandingkan boosters. Ini menunjukkan bahwa penulis buku TP Sejarah lebih banyak memberikan evaluasi positif ketimbang negatif. Mengingat bahwa penulisnya tiga orang, elemen self-mentions tidak ditemukan.

Dalam buku TP Sejarah Kelas XI didapatkan temuan bahwa penulis lebih berani menggunakan heteroglossia yang berupa pendapat untuk menyokong argumennya dibandingkan dengan penulis buku TP Sejarah Kelas X. Pronomina kamu 
dan kalian digunakan, baik dalam bentuk instruksi soal maupun uraian materi.

Dalam buku TP Sejarah Kelas XII, sama halnya dengan buku TP Sejarah Kelas XI, ditemukan heteroglossia di awal Bab I. Kutipan berupa pendapat itu dijadikan landasan dalam membentuk wacana pada buku tersebut.

\section{REFERENSI}

Biber, D. (2006). Stance in spoken and written university registers. Journal of English for Academic Purposes, 5(2), 97-116.

https://doi.org/10.1016/j.jeap.2006.05. 001

Dzeverdanovic-Pejovic, M. (2015). Genre Analysis of Linguistic Abstracts in Montenegrin and English. In I. Lakic, B. Zivkovic, \& M. Vukovic (Eds.), Academic Discourse Across Cultures. Newcastle: Cambridge Scholars Publishing.

Hyland, K. (2005). Stance and engagement: A model of interaction in academic discourse. Discourse Studies, 7(2), 173-192.

https://doi.org/10.1177/146144560505 0365

Kafes, H. (2018). Stance in Academic Writing. European Journal of Education Studies, 4(2), 1-16. https://doi.org/10.5281/zenodo.116508 8

Kurniawan, E., Lubis, A. H., Suherdi, D., \& Danuwijaya, A. A. (2019). Rhetorical organization of applied linguistics abstracts: Does scopus journal quartile matter? GEMA Online Journal of Language Studies, 19(4), 184-202. https://doi.org/10.17576/gema-20191904-10

Martin;, J. R., \& White, L. R. R. (2005). The Language of Evaluation: Appraisal in English. https://doi.org/10.1007/978-1-46145547-9

Murfi, A. (2014). Bias Gender dalam Buku Teks Pendidikan Agama Islam dan Kristen. Jurnal Pendidikan Islam, 3(2), 267. https://doi.org/10.14421/jpi.2014.32.2 67-288

Purwanta, H. (2013). Evaluasi Isi Buku Teks Pelajaran Sejarah Pada Masa Orde Baru. Jurnal Cakrawala Pendidikan, (3), 424-440. https://doi.org/10.21831/cp.v0i3.1551

Sayah, L., \& Hashemi, M. R. (2014). Exploring stance and engagement features in discourse analysis papers. Theory and Practice in Language Studies, 4(3), 593-601. https://doi.org/10.4304/tpls.4.3.593601

Yang, W. (2016). Evaluative language and interactive discourse in journal article highlights. English for Specific Purposes, 42, 89-103. https://doi.org/10.1016/j.esp.2016.01.0 01 